\title{
Conflict within irrigation districts may limit water transfer gains
}

\author{
Michael D. Rosen
}

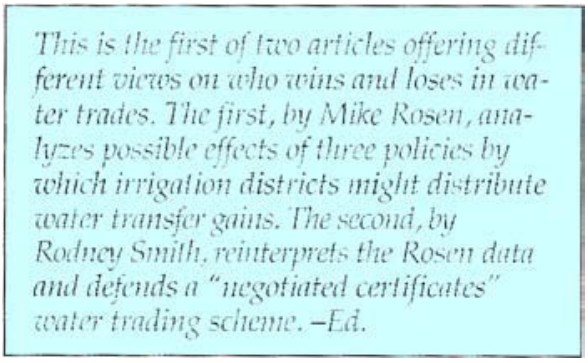

The Imperial Irrigation District and the Metropolitan Water District (MWD) of Southern California have recently concluded an agreement which is historic because of its long-term nature and the volume of water to be transfered. Imperial will transfer 106,110 acre-feet of water to MWD annually for 35 years in exchange for MWD providing funds for Imperial conservation projects. The projects are to be completed by 1994 and paid for by MWD over a 35-year period for a total cost of $\$ 222$ million. The effective price of water to Metropolitan will be about $\$ 100$ per acre-foot per year.

Proposals for alternative uses for these funds could become a major source of conflict within the Imperial district. Three potential policies are examined in this article. At present, Imperial receives and controls the funds, but the district is contemplating ways to allow district landowners and farm operators to receive funds directly.

Water transfers have been promoted as voluntary transactions in which there can be no losers. But decision-making within water districts is collective in nature, and intra-district conflict may arise. Individual members of districts may have reason to oppose transfers, and aggregate benefits may not be realized.
In California, competition for scarce water resources among urban and rural water users and among rural irrigation districts has had a long and colorful history. Today, in the 1990s, water transfers from agricultural to urban regions have been proposed as a possible solution to water shortages. Such "water transfers" can refer to water trades, water markets, water exchanges, water banks, or any other idea to save, create, or allocate water by treating water as an economic good.

Competition among users within the same district or between individual district members and the district entity itself has been a less visible topic. Water transfers may introduce new sources of conflict within a water district: What sources of water within the district will be available for transfer? And who within the district will benefit by the transfer?

Water trades may raise the price of irrigation water; as a result, farmers may suffer a decline in net income from farm operations. To compensate them for the decline in net income, revenues earned from the transfer can be directly rebated to district members. Or, to lower the effective price of water, revenues can be invested in conservation, which may include districtlevel projects controlled by the district's management or farm-level projects undertaken by individual farmers.

Here, we look at the farm-level economic effects of the water transfer between the Imperial Irrigation District and the Metropolitan Water District of Southern California. We take on the point of view of an individual farmer within Imperial. The water district is comprised of members who are not homogeneous in nature and who may not all benefit from the water transfer. Those who perceive them- selves as incurring losses have reason to oppose the transfer.

\section{Water transfer agreement}

Two districts in Southern California have recently concluded a water transfer agkeement. The Imperial Irrigation District is a large irrigated agricultural area of 500,000 gross acres near the border of Mexico. Imperial diverts 2.5 million acrefeet per year from the Colorado River. Imperial farms contribute about one-half billion dollars in gross income to the California farm economy. Field crops use $85 \%$ of the water and provide $55 \%$ of the value of farm output. Garden and permanent crops use $15 \%$ of the water and provide the other $45 \%$ of the value of farm output. The Metropolitan Water District of Southern California is a wholesaler of water to retail urban water districts in Los Angeles, Orange, and San Diego counties. Total water use in the Metropolitan service area by 14 million customers is 3.7 million acre-feet. Up to 1.2 million acre-feet are diverted from the Colorado River.

Imperial and Metropolitan officials first met in April 1984 to negotiate a water transfer. By September 1985, a tentative agreement was reached between the two boards of directors. Metropolitan would pay for district-level conservation facilities in Imperial, and Metropolitan would receive in exchange the water that would be saved. The transfer volume was to be 100,000 acre-feet per year for 35 years. The transfer price was to be $\$ 100$ per acre-foot. The annual payment from Metropolitan to Imperial was to be $\$ 10$ million, or $\$ 350$ million over the life of the contract. A series of public meetings were held throughout Imperial to showcase the tentative contract. In the face of stiff opposition, the Imperial board formally voted not to ratify the agreement. 
Negotiations were later reopened and a final agreement was reached and signed in December 1989. The new agreement allows Imperial more flexibility in the choice of conservation projects. The volume of water to be conserved and made available is 106,110 acre-feet per year for 35 years. The payments are estimated in 1988 dollars to be $\$ 98$ million over 5 years for irrigation system improvements and on-farm water management in Imperial, $\$ 23$ million to offset indirect costs of the project, $\$ 10$ million for operation and maintenance and an additional $\$ 2.6$ million a year for 35 years for maintenance, operations, and liability costs. The project is to be completed in 1994 at a total cost to MWD over 35 years of $\$ 222$ million (according to MWD engineer Jan Matusak). The transfer

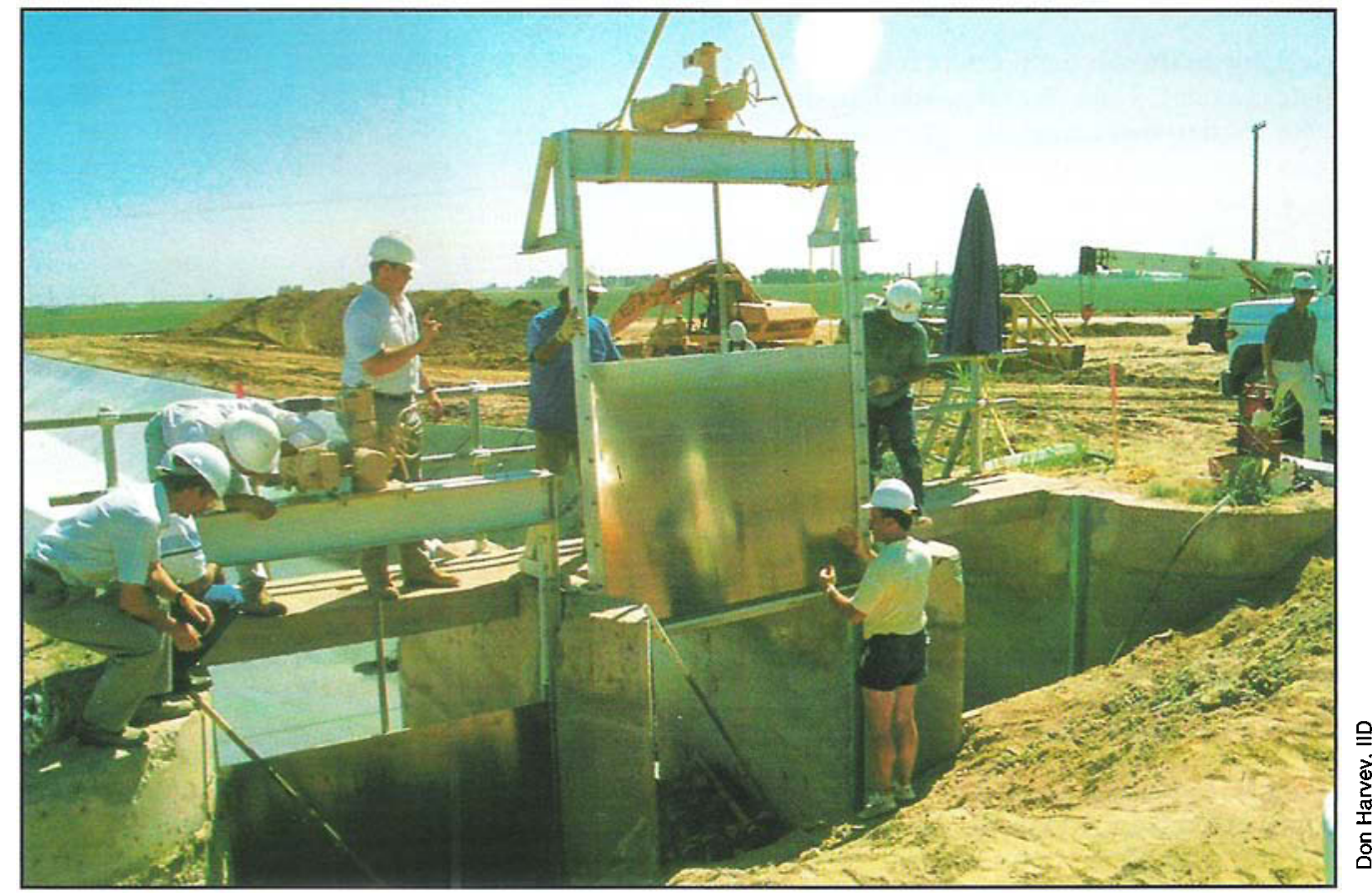
represents the first major new water supply for MWD in 25 years.

Federal legislation has also been passed that gives Metropolitan the authority to finance and construct additional projects in Imperial. Senate Bill 795 became public law in October 1988. No profits for Imperial are required by the legislation. The federal legislation mirrors the California water doctrine of physical solution. If a claimant maintains that long-established methods of using water by a second claimant are wasteful, then the claimant may look for some physical solution at his own expense that preserves existing water rights. The claimant in this case would be Metropolitan claiming that Imperial had been wasteful. The federal legislation includes the safeguard that Imperial can obtain use of the conserved water, if needed, or even exercise the right to be the sole participating contractor for the project.

\section{Imperial farmers}

A survey of Imperial farmers was conducted and programming models were constructed to simulate how individual farmers within Imperial may respond to the water transfer.

A representative survey of Imperial farmers was conducted with in-person interviews by two-member teams. A stratified random sample was employed so that the farms selected were ordered roughly by size. Data collected included crop acreage, water use, average production costs, and average net income. Of the 31 operators in the completed survey, $26^{\circ}$ grew wheat, 21 cotton, 26 alfalfa hay, 17 sugarbeets, and 11 garden and permanent crops. The farmers surveyed operated on 58,780 gross acres of land and used

320,200 acre-feet of water or about $12 \%$ of the land and water used annually by agriculture in the district.

The survey was taken several years ago, and changes in the crop mix have occurred in the intervening years. Cotton has almost disappeared from the Imperial district due to the development of resistance by cotton pests to pesticides.

Gross incomes in Imperial range from $\$ 70$ per acre-foot for alfalfa to $\$ 2,400$ per acre-foot for garden crops. The average gross income from farm operations was $\$ 240$ per acre-foot; average net income was $\$ 50$ per acre-foot. Most of the higher-risk, higher-income garden and permanent crops were grown on rented land. Farm size, farm water use, and percentages of acres owned and acres in garden and permanent crops are shown for each survey farm in table 1.

Farm production is characterized by decreasing marginal physical product and increasing risk as output levels increase. Individual farm access to irrigation water is not restricted and is allocated solely by price. We assume that the behavior of the farm operators, as observed in the survey, is the optimal behavior, and that marginal net income from the last acre-foot of water applied on each farm is zero. Average cost data and observed output quantities were used to construct marginal cost functions and profit functions for each of the 31 survey farms. Profit functions then were developed into farm-level quadratic programming models for each survey farm.

\section{Policy responses}

We can use farm-level models to estimate the price elasticities of demand for
Workers install automated, non-leaking aluminum gates in place of older wooden structures, a conservation project funded by the recent water transfer agreement between IID and MWD.

irrigation water. Elasticities measure the responsiveness of changes in demand for irrigation water to changes in the price of water. Price elasticities indicate the degree to which policies based on changes in price may be effective in managing demand.

The price of water in the survey was $\$ 7.50$ per acre-foot. The elasticities were estimated at -0.32 over the price range from $\$ 7.50$ to $\$ 15,-0.53$ from $\$ 15$ to $\$ 22.50$, and -0.63 from $\$ 22.50$ to $\$ 30$. A negative price elasticity indicates that demand for irrigation water by farmers will decrease, given an increase in the price of water. The elasticities obtained from the farm-level models are consistent with elasticities from models constructed from regional data. Results indicate that the availability of water associated with water markets could be substantial because higher prices are increasingly effective in reducing demand.

We have identified for Imperial three district policy responses that are available to implement the water transfer. Each policy is characterized by the post-transfer supply of irrigation water, the price for water charged by Imperial, and the aggregate demand for water by farm operators. The policies are labeled: expanding the resource, negotiated certificates, and maintaining the resource.

First, engineering data on the costs of conservation were used to determine the effects on the post-transfer water supply 
available to the survey farmers under each district policy. Next, the farm-level models were used to determine the aggregate demand for water by survey farmers. The appropriate price of water to be charged by Imperial under each policy is the price that equates aggregate demand with the post-transfer supply. Then, we determined for each survey farm the production impacts and income effects under each policy response. Net farm income is derived from three sources. The farm-level models estimate net income from farm operations as a function of the price of water. Each farm operator is also assigned a share of the water district's operating costs and revenues. Each farm operator, depending on the policy response, may also share in the transfer revenue. Aggregate supply results and the price of water, for each policy response, are shown in table 2. Aggregate benefits to survey farmers under each policy are shown in table 3.

Expanding the resource. One policy is to invest all transfer revenues into district-level conservation projects. Projects available to expand the resource include spill systems, canal seepage control, regulatory reservoirs, and lining the main diversion canal from the Colorado River.

\begin{tabular}{|c|c|c|c|c|}
\hline $\begin{array}{l}\text { Farm } \\
\text { survey } \\
\text { no. }\end{array}$ & $\begin{array}{l}\text { Farm } \\
\text { size }\end{array}$ & $\begin{array}{l}\text { Water } \\
\text { - use }\end{array}$ & $\begin{array}{l}\text { Owned } \\
\text { acres }\end{array}$ & $\begin{array}{c}\text { Garden } \\
\text { crops }\end{array}$ \\
\hline & acres & acre-feet & \multicolumn{2}{|c|}{......................... } \\
\hline 1 & 413 & 2,291 & 100.0 & 0 \\
\hline 2 & 130 & 875 & 0 & 0 \\
\hline 3 & 141 & 827 & 100.0 & 0 \\
\hline 4 & 231 & 1,386 & 0 & 0 \\
\hline 5 & 1,112 & 6,677 & 0 & 0 \\
\hline 6 & 1,248 & 6,981 & 0 & 14.8 \\
\hline 7 & 378 & 1,879 & 0 & 58.2 \\
\hline 8 & 698 & 5,134 & 0 & 0 \\
\hline 9 & 1,040 & 6,535 & 48.1 & 0 \\
\hline 10 & 582 & 3,649 & 0 & 0 \\
\hline 11 & 430 & 2,018 & 0 & 0 \\
\hline 12 & 1,170 & 5,217 & 7.7 & 0 \\
\hline 13 & 1,270 & 8,175 & 0 & 0 \\
\hline 14 & 559 & 3,361 & 100.0 & 0 \\
\hline 15 & 1,545 & 7,215 & 38.2 & 46.0 \\
\hline 16 & 770 & 5,030 & 10.4 & 0 \\
\hline 17 & 907 & 4,339 & 100.0 & 38.6 \\
\hline 18 & 2,924 & 14,274 & 16.2 & 37.4 \\
\hline 19 & 1,752 & 7,633 & 0 & 75.6 \\
\hline 20 & 1,823 & 11,221 & 19.3 & 0 \\
\hline 21 & 1,040 & 6,150 & 50.0 & 0 \\
\hline 22 & 3,167 & 17,004 & 11.2 & 4.7 \\
\hline 23 & 1,814 & 10,732 & 92.6 & 0 \\
\hline 24 & 2,999 & 20,798 & 14.4 & 0 \\
\hline 25 & 6,269 & 31,676 & 15.3 & 64.9 \\
\hline 26 & 2,254 & 11,957 & 0 & 30.7 \\
\hline 27 & 2,557 & 14,713 & 46.0 & 32.0 \\
\hline 28 & 4,737 & 23,341 & 100.0 & 0 \\
\hline 29 & 4,175 & 22,260 & 100.0 & 21.3 \\
\hline 30 & 6,803 & 39,930 & 94.0 & 0 \\
\hline 31 & 3,846 & 16,929 & 79.6 & 0 \\
\hline Totals & 58,780 & 320,200 & 46.9 & 17.9 \\
\hline
\end{tabular}

Conservation costs range from $\$ 16$ to $\$ 212$ per acre-foot per year each year for saved water.

The share of the transfer from the survey farms is 12,500 acre-feet. Diversions from the Colorado River for the survey farmers are reduced by $4 \%$, from 358,000 to 345,500 acre-feet. But the efficiency of the water delivery system may be increased by conservation so that deliveries to the farm gate actually expand. Current rate of delivery losses in Imperial, based on engineering studies, is $11 \%$ of diversions. Conservation can potentially reduce delivery losses to $4 \%$ of diversions. The net effect is that deliveries may increase by $3 \%$, from 320,200 to 333,000 acre-feet. The effective price of water, as shown in table 2 , drops to $\$ 5.35$ per acre-foot.

Expanding the resource is the policy advocated by the Imperial board of directors. District plans do not involve any type of compensation or distribution of the transfer revenues directly to farmers. Aggregate net gain for the survey farmers compared with the pretransfer case is only. $\$ 82,000$. Net gain under this policy is about $\$ 6$ per acre-foot of traded water or about $\$ 2,600$ per farm. Costs of conservation are much greater than the marginal value of crop production.

Negotiated certificates. Rodney Smith has proposed in the Journal of Policy Analysis and Management (1989) a version of water rights he labels "negotiated certificates." (See p. 8.) Farmers are provided direct incentives to idle land or shift their crop mix. Water saved from these actions is used to fulfill the transfer contract. The Smith plan is consistent with current irrigation law, retains marginal cost pricing of water, and provides an economic rationale for the distribution of compensation.

First, district water rights are apportioned among district members on the basis of assessed valuation of land excluding improvements. Each player is awarded one certificate for each acre-foot of that player's share of water rights.

Next, the water district needs to acquire enough certificates to fulfill the terms of the transfer. Each member of the district makes a tender offer to the district for the number of certificates that player is willing to give up. The compensation to the member will be a proportional share of the transfer revenue. If more shares are tendered than needed, the acceptance of shares will be pro-rated. The payment is in cash directly to members.

There is no investment in conservation under this policy. Deliveries are reduced from 320,200 to 309,000 acre-feet. The water price rises from $\$ 7.50$ to $\$ 8.90$ per acrefoot. Net income of survey farmers is increased by $\$ 1.234$ million. Net gain is about $\$ 99$ per acre-foot of traded water or $\$ 39,800$ per farm.

Maintaining the resource. The third policy is to invest only some transfer revenues into conservation projects. The goal is to maintain net water deliveries to survey farmers at the pretransfer level of 320,200 acre-feet. Lower diversions due to the water transfer are offset by higher delivery efficiency due to conservation. The trade reduces water diversions from 358,000 to 345,500 acre-feet. About onefourth of transfer revenues are invested to reduce delivery losses to 25,300 acre-feet. Remaining revenues are paid directly to farmers.

The water price is maintained at $\$ 7.50$ per acre-foot. Aggregate net income of the survey farmers increases by $\$ 941,000$. Net gain under this policy is about $\$ 75$ per acre-foot of traded water or $\$ 30,400$ per farm.

\section{Rejected policy}

The gain in aggregate net benefits under the policy of negotiated certificates may approach $10 \%$ of aggregate net farm income. Yet action, such as idling land, has been rejected by the Imperial board as only a last resort to fulfilling the transfer contract. We look at how individual farmers may respond to the water transfer policies and whether the farmers' collective choice of the policy response is consistent with the board's preference.

The policy response most preferred by an individual farmer is that policy among the four that yields the most net benefits to that farmer. The least preferred is the policy that yields the least net benefits. For each survey farm, we determine net farm income under each policy and compare the results to determine the preferred policy.

The policy of expanding the resource, as shown in table 3 , is the most beneficial for the 11 farm operators who rent smaller tracts of land and grow mostly lower-risk field crops. As a group, they own only 5\% of the land they operate and devote only $9 \%$ of that land to garden and permanent crops. The policy of negotiated certificates is most beneficial for the 11 farmers who own about $83 \%$ of the land they operate but devote only $5 \%$ of the land to garden and permanent crops. The policy of maintaining the resource is the most beneficial for the nine farm operators who rent larger tracts of land and who include in their crop mix higher-risk and higher-income garden crops.

Benefits from trade under negotiated certificates (the Smith policy) are distributed much less evenly than under the other two policy responses. (For additional discussion, see (See p. 8.) As shown in table 3,17 survey farmers, more than half 


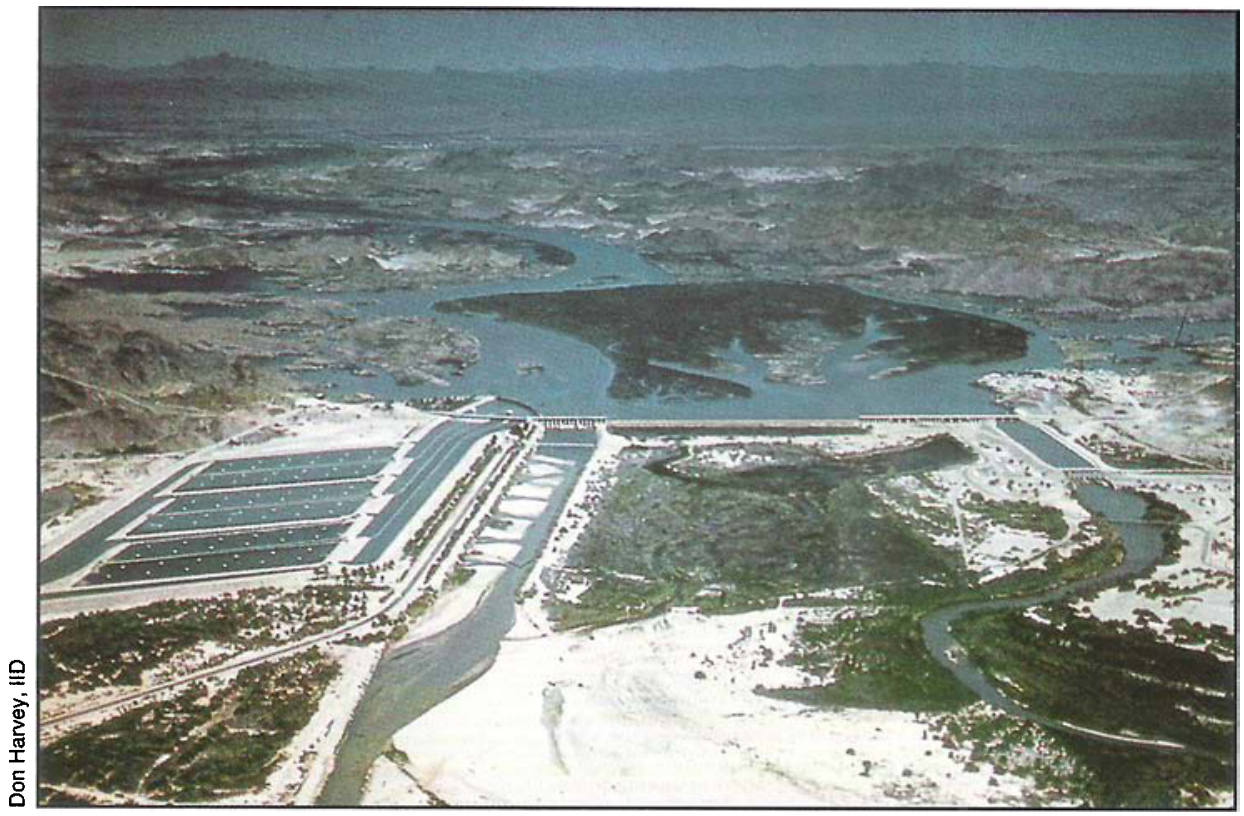

IID's Imperial Dam has a water-purifying function, cleansing the Colorado River water of silt.

of the members surveyed, would incur a loss from the water transfer under the Smith policy and would be worse off compared with their pretransfer situation. The Smith policy has a bias towards landowners and against renters. Landowners will receive direct compensation because the trade benefits are distributed based on land values. Operators who rent land will receive no direct compensation and will be penalized through higher water prices. Conservation-oriented policies are acceptable to renters because farm operators can benefit from less expensive irrigation water.

In the short run, losses under the Smith policy provide a reason for renter-operators to oppose water transfers. In the long run, the magnitude of the losses may be offset by downward adjustments in land rental rates due to market factors or by shifts away from water to other farm inputs such as labor or capital. In any case, there is no provision for renter-operators to share in the transfer revenues or to have a reason to actively support water transfers.

\section{Conclusions}

The concept of combining water transfers with direct farm-level incentives was not adopted with the Imperial-Metropolitan trade. Attempts to develop direct farm-level incentives were initiated in 1991 with consideration in the California

Legislature of Assembly Bill 2090. The bill would allow farmers to individually negotiate to sell water outside of district boundaries.

This study shows that direct farm-level incentives, although complicated and difficult to implement, are needed to increase the aggregate benefits from water transfers. Based on direct incentives, we may envision that the number of certificates tendered would be many multiples of the number needed. The Imperial transfer is to be 106,110 acre-feet per year at about $\$ 100$ per acre-foot. The regional model of Imperial implies that a transfer price as low as \$25 would encourage farmers in Imperial to tender certificates for 1 million acre-feet. The Smith plan, if ever it were tried, would provide a solid test of claims by water policy reformers that desire and potential exist for much larger water transfers than are being discussed.

The study also uncovers reasons for substantial opposition to the Smith plan. We used farm-level survey data to provide a richer base of information than an aggregate model using regional data. The aggregate models ignore that water districts are composed of members with different circumstances and preferences. More than half of the farm operators would be worse off under the Smith plan than if the water market were not implemented. Districts may need to implement sharing rules to lessen the conflict between landowners and renters.

In the face of $A B$ 2090, the challenge to district management is twofold. The districts will want to encourage landowners to maintain collective rather than individual bargaining positions, to maximize aggregate transfer revenues. At the same time, the districts must consider imposing sharing rules on landowners, to lessen opposition within the district from renters.

Policies oriented towards district-level use of the transfer revenues are easier to implement, so that direct farm-level incentives may not evolve. The collective choice to invest all transfer revenues into districtlevel conservation projects implies that the water district may be unable to take full advantage of the potential benefits to be earned from water transfers.

$M . D$. Rosen is an economist in private practice in Sacramento, and was formerly a graduate student in the Department of Agricultural Economics, UC Davis.

This study was supported by a grant from the UC Water Resources Center and by the Department of Agricultural Economics, UC Davis. Use of the survey data was provided by Kelly Zering, Steve Hatchett, Ray Huffaker, and Sandy Archibald, all formerly graduate students in the Department of Agricultural Economics, UC Davis. 